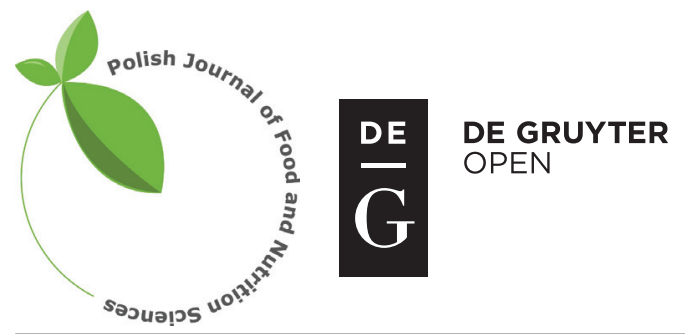

Pol. J. Food Nutr. Sci., 2018, Vol. 68, No. 2, pp. 141-148

DOI: $10.1515 /$ pjfns-2017-0024 http://journal.pan.olsztyn.pl

Original research

Section: Food Quality and Functionality

\title{
Improving Storability of Strawberries with Gaseous Chlorine Dioxide in Perforated Clamshell Packaging
}

\author{
Valentina Chiabrando*, Nicole Giuggioli, Marco Maghenzani, Cristiana Peano, Giovanna Giacalone \\ Department of Agricultural, Forest and Food Sciences (DISAFA), Università degli \\ Studi di Torino, Largo Paolo Braccini 2, 10095 Grugliasco, TO, Italy
}

Key words: strawberry, chloride dioxide, gaseous treatment, gas-generating pad

\begin{abstract}
A chlorine dioxide generating pad has been used as postharvest treatment to maintain the quality and safety of strawberries in two different storage conditions. During the short storage time $\left(3\right.$ days at $4{ }^{\circ} \mathrm{C}+2$ days at $\left.20^{\circ} \mathrm{C}\right)$ fruit treated with $\mathrm{ClO}_{2}$ maintained better quality parameters, as color, titratable acidity, total soluble solids, anthocyanins, antioxidant capacity and lower values of weight loss. During the long storage time $\left(12\right.$ days at $\left.2^{\circ} \mathrm{C}\right)$, the parameters related to postharvest quality were generally preserved and the effect of $\mathrm{ClO}_{2}$ was positive to reduce the total yeast and mold, except the last period of the experiment when the $\mathrm{ClO}_{2}$ gas-generating pad was probably exhausted. The sensory evaluation revealed that the sanitization with $\mathrm{ClO}_{2}$ maintained a global positive acceptance in particular during the short storage time. The results suggest that this treatment may be suitable to maintain the quality during short storage and long storage until 8 days and it may be an important alternative sanitizer thanks to the positive action against the yeast and mold without modifying the quality of the strawberries.
\end{abstract}

\section{INTRODUCTION}

Strawberry (Fragaria X ananassa Duch.) is one of the most popular summer fruit and is known for its taste and flavor. It is a rich source of flavonoids, especially anthocyanins, as well as vitamins, minerals and amino acids that have a beneficial effect on health [Bonarska-Kujawa et al., 2012]. However, strawberries are highly delicate and perishable fruits, which results in their short post-harvest shelf-life due to mechanical injury, water loss, physiological disorders, high respiration rate, off-flavors, and textural losses [Vargas et al., 2006]. Moreover, susceptibility of strawberries against postharvest fungal damage like Grey mold rot caused by Botrytis cinerea and Rhizopus rot caused by Rhizopus stolonifer is much higher than in the other crops. The postharvest losses can reach as high as $40-50 \%$ during storage period [Maas, 1998]. Therefore, fruit processing industry tries to find technologies to minimize the undesirable physicochemical and physiological changes and to maintain quality of strawberry during postharvest storage.

In order to extend shelf-life and to limit fungal losses of the fresh strawberries, a number of treatments such as edible coating application, calcium dipping, UV radiation, ultrasonic treatment and modified atmosphere packaging have been studied [Aday \& Caner, 2011; Cao et al., 2010; Peano et al., 2014]. Chemical sanitizers and fungicides can be used as well [Lopez-Gomez et al., 2009]. However, some methods

\footnotetext{
* Corresponding Author: Tel.: +39 0116708938; Fax: +39 0116708658

E-mail: valentina.chiabrando@unito.it (V. Chiabrando)
}

are not commercially reasonable, expensive, time-consuming and off-flavor developing.

The use of chlorine washing is probably the most commonly used method for decontamination of the fresh fruit and vegetables and to improve the quality but it has some adverse effects such as generation of toxic by-products [Sy et al., 2005b]. Therefore, alternative strategies have to be used to keep strawberry quality for a longer period. Chlorine dioxide $\left(\mathrm{ClO}_{2}\right)$ is a powerful sanitizing agent and decontaminant and does not react with organic compounds to produce toxic chlorinated by-products. It has a higher oxidizing capability than chlorine. $\mathrm{ClO}_{2}$ is a promising chemical found to be able to reduce and delay senescence, including browning and disease, on a wide range of products including blueberries, raspberries, strawberries and apricot [Aday et al., 2013; Shin et al., 2012; Sy et al., 2005a; Zhong et al., 2006]. Moreover, the molecules of $\mathrm{ClO}_{2}$ can be integrated into the package as sachets/ pads containing volatile antimicrobial agents [Appendini \& Hotchiss, 2002]. $\mathrm{ClO}_{2}$ gas has been shown to be more effective than aqueous formulation at the same concentration due its greater diffusivity into the tissues [Han et al., 2001]. The applications of gaseous $\mathrm{ClO}_{2}$ maintained higher fruit quality on longan fruit [Saengnil et al., 2014], blueberries [Zhang et al., 2015], sweet cherry [Colgecen \& Aday, 2015], and apricot [Wu et al., 2015].

Therefore, the objective of this study was to evaluate the efficacy of easy-to-use chlorine dioxide gas generating pad on strawberries postharvest quality, nutritional components and microbial growth during storage period. 


\section{MATERIALS AND METHODS}

\section{Sample preparation and storage conditions}

Strawberries (cv. Portola) were harvested from a commercial orchard of the Agrifrutta Soc. Coop. SRL (Piedmont, Italy) at full ripeness and directly placed in commercial plastic baskets (30), clamshell type (L13.5x w9.0 x h2.5 cm, perforated ( 8 holes, $1 \mathrm{~mm}$ diameter $\emptyset$ ), polyethylene terephthalate). Fruits with physiological disorders or fungal spoilage were discarded. The baskets were divided into two groups randomly of 15 box each. In the first group a chlorine dioxide (CD) gas generating pad (Oplon Pure Science, Ltd., Ness Tsiyona, Israel) was applied on the top lids of the clamshells and the second group was used as control.

The strawberries were maintained in dark conditions and controlled temperature at two different storage times to simulate different distribution supply chains. To simulate a short distribution chain that was similar to retailer conditions, the clamshells were placed in a storage room at $4 \pm 1{ }^{\circ} \mathrm{C}$ for 3 days and then after this cool storage the fruits were removed and stored for 2 days at $20 \pm 1^{\circ} \mathrm{C}$. To simulate the long supply chain the strawberries were maintained at $2 \pm 1^{\circ} \mathrm{C}$ up to 12 days. Three randomly selected clamshells/treatments $(0.250 \mathrm{~kg}$ of strawberry fruits, each about $10-15 \mathrm{~g})$ were sampled for each time point respectively 0,3 and $3+2$ days for the short storage time and $0,4,8$ and 12 days for the long storage time.

\section{Weight loss}

Sample baskets were numerated at the start of the experiment and the weight of each one was recorded at each time point respectively 0,3 and $3+2$ days for the short storage time and after 4, 8 and 12 days for the long storage time. An electronic balance (SE622, WVR Science Education, USA) with an accuracy of $10^{-2}$ was used. The weight loss was reported as the percentage (\%) of the initial weight per baskets. The results were expressed as an average of three replicates.

\section{Color}

External color was measured on 15 fruits for each treatment, using a Minolta colorimeter CR-400 (Chroma Meter, Minolta, Japan). Chromatic analyses were carried out following the CIELAB system. Values of $\mathrm{L}^{*}, \mathrm{a}^{*}$ and $\mathrm{b}^{*}$ were measured to describe a three-dimensional color space. The color of fruits was also expressed as $\mathrm{h}^{\circ}$ (hue angle). Before readings were taken during each sampling day, the colorimeter was calibrated using calibration white tiles.

\section{Sensory evaluation}

Five strawberries selected at random from each treatment were presented to six panelists previously trained with commercial samples to perform a sensory evaluation of the stored strawberries after 3 and $3+2$ days for the short storage time and after 4, 8 and 12 days for the long storage time. The descriptors considered were: presence of visible mold, presence of moisture, presence of water in the box, presence of anomalous odors, color of skin and leaf, global appearance and aroma. During each session, the samples were presented in randomized order to the panelists, who judged the param- eters with a five grade scale, from 5 (excellent /absence) to 0 (unusable /presence) according to Aday \& Caner [2011] with some modification. Results were expressed as a sensory index calculated as the sum of all the scores for each evaluated descriptor.

\section{Total soluble solid content, titratable acidity and $\mathbf{p H}$}

Total soluble solid content (TSSC) of strawberry was determined in the juice of five strawberries randomly selected from each treatment using a handheld Atago digital refractometer model PR-32 (Atago, Italia, Milan, Italy). Titratable acidity (TA) and $\mathrm{pH}$ were determined by titrating the juice with $0.1 \mathrm{M} \mathrm{NaOH}$ to $\mathrm{pH} 8.1$ using an automatic titrator (Titration workstation Titralab AT1000Series, Radiometer Analytical, Villerbaunne, France). Three replicates of each treatment and each storage time were taken and the results of TSSC and TA were expressed as ${ }^{\circ}$ Brix and meq/L (milliequivalents of organic acid per $\mathrm{L}$ of strawberry juice).

\section{Determination of anthocyanins, total phenolics and antioxidant capacity}

Strawberry samples were extracted with methanol [Chiabrando \& Giacalone, 2015]. Extracts were stored at $-26^{\circ} \mathrm{C}$ until analyzed. The total anthocyanin content was evaluated by the method of Cheng \& Breen [1991]. The results were expressed as mg of cyanidin-3-O-glucoside equivalents per $100 \mathrm{~g}$ of fresh weight and were calculated as follows:

\section{$\mathrm{TA}(\mathrm{mg} / 100 \mathrm{~g})=\mathrm{A} \times \mathrm{MW} \times \mathrm{DF} \times 10^{-3} / \varepsilon \times 1 \times \mathrm{W}$}

where: $\mathrm{A}=\left(\mathrm{A}_{510}-\mathrm{A}_{700}\right)_{\mathrm{pH} 1.0}-\left(\mathrm{A}_{510}-\mathrm{A}_{700}\right)_{\mathrm{pH} 4.5} ; \mathrm{MW}=$ molecular weight $(449.2 \mathrm{~g} / \mathrm{mol}) ; \mathrm{DF}=$ dilution factor; $1=$ path length $(1 \mathrm{~cm}) ; \varepsilon=$ molar extinction coefficient for standard $(26,900 \mathrm{~L} / \mathrm{mol} \mathrm{cm})$; and $\mathrm{w}=$ weight of the sample.

A mean value of three replicate measurements per treatment was obtained. Total phenolics content was determined by the method described by Waterhouse [2002] with Folin-Ciocalteu reagent using gallic acid as a standard. Absorbance was measured at $765 \mathrm{~nm}$. Results were expressed as mg gallic acid equivalents (GAE)/100 g of sample.

The antioxidant capacity of strawberries was measured as their ability to reduce $\mathrm{Fe}^{3+}$ by ferric-reducing antioxidant power (FRAP) assay [Pellegrini et al., 2003]. Results were expressed as $\mathrm{mM} \mathrm{Fe}{ }^{2+}$ per $\mathrm{kg}$ of fresh weight of fruits.

\section{Vitamin $C$ content}

For vitamin $\mathrm{C}$ analysis according to Sanchez-Moreno et al. [2003] and González-Molina et al. [2008], $10 \mathrm{~g}$ of strawberry fruit were combined with $10 \mathrm{~mL}$ of extraction solvent (methanol:water 5:95, v/v). The sample was homogenized with an Ultra-Turrax T-25 Tissue homogenizer (IKA®Labortechnik, Saufen, Germany) for $1 \mathrm{~min}$ at relative centrifugal force (RCF) $45158 \times g$ and then centrifuged for $15 \mathrm{~min}$ at RCF $1254 \times g$ (Centrifuge AVANTITM J-25, Beckman Instruments Inc.). The $\mathrm{pH}$ value of samples was adjusted to 2.2-2.4 and the extract was adsorbed on a C18 Sep-Pak cartridge (Waters Associates, Milford, MA, USA). The resultant solution was added to 1,2-phenylenediamine dihydrochloride (Fluka Chemika, Neu-Ulm, Switzerland) and left to 
stand for 37 min before HPLC analysis at room temperature. The chromatographic system (Agilent) was equipped with a Kinetex-C18 column ( 4.6 x $150 \mathrm{~mm}, 5 \mu \mathrm{m}$, Phenomenex, Torrance, CA, USA), a pump and a diode array detector. The system was controlled through HPLC online software (Agilent) at $40^{\circ} \mathrm{C}$. The mobile phase (isocratic) comprised $50 \mathrm{mM}$ monobasic potassium phosphate and $5 \mathrm{mM}$ cetrimide (Sigma-Aldrich Corporation, Saint Louis, USA) in methanol:water $(5: 95 \mathrm{v} / \mathrm{v})$. The flow rate was $0.9 \mathrm{~mL} / \mathrm{min}$. The total run time was $15 \mathrm{~min}$. The detector was set at $261 \mathrm{~nm}$ for AA and 348 for DHAA. External calibration curves for ascorbic acid and dehydroascorbic acid, respectively, were used for quantification. The content of vitamin $\mathrm{C}$ was calculated by the sum of ascorbic and dehydroascorbic acid contents and expressed as $\mathrm{mg} / 100 \mathrm{~g}$ fresh weight. Three replicate analyses were performed.

\section{Yeast and mold evaluation}

Total yeast and molds were examined according to the methods described in the Compendium of Methods for the Microbiological Examination of Foods [Vanderzant \& Splittstoesser, 1992]. A $270 \mathrm{~mL}$ of peptone buffered water (Sigma Italiana SRL, Ozzano Emilia, Italy) was added to $30 \mathrm{~g}$ of fresh strawberry sample in a Stomacher® bag using a blender (Stomacher®400 Circulator, Seward, Worthing, UK). Appropriate dilutions were applied. Rose Bengal agar (Sigma Italiana SRL, Ozzano Emilia, Italy) was utilized for the yeast and molds evaluations. All the plates were incubated at $30^{\circ} \mathrm{C}$ for 5 days. Microbial counts were expressed as $\log$ colony forming units/g (log CFU/g).

\section{Statistical analysis}

The statistical analysis system SPSS (statistics version 22 IBM) was used for analysis of the data. Data were treated by one-way ANOVA. Statistical analysis was carried out separately for short and long storage time. Shelf-life period $(3+2)$ was not compared with 3 days storage because the storage conditions of temperature were changed and therefore not comparable. Significant differences for treatments were detected using the least significant differences (LSD) at a significance level of 0.05 and the means were separated using the Tukey's test.

\section{RESULT AND DISCUSSION}

\section{Weight loss}

Respiration and moisture evaporation on the surface of fruit are two factors recognized as the most important for the weight loss of strawberries [Hernandez-Munoz et al., 2008]. In this work, considering the short period no significant differences were observed between the $\mathrm{ClO}_{2}$ treated (CD) samples and control (Table 1). On the contrary, during the long storage period evaluated, the weight loss of CD samples was significantly lower after 8 and 12 days compared to control. The same result was observed by Aday \& Caner [2011], where the lower weight in the CD samples was probably caused by effect of $\mathrm{ClO}_{2}$ on the microorganisms. The low proliferation of microorganism on the surface of fruits affects the enzymatic activity [Wang et al., 2011], the respiration rate and the ethylene biosynthesis [Aday \& Caner 2011; Guo et al., 2013] with the effect of limiting the evaporation and the post-harvest metabolic process [Sun et al., 2014].

\section{Color}

Color degradation of strawberry is usually caused by two factors: loss of anthocyanin pigment, which is a pigment contributing to the red color, and the increase of the respiration rate-enzymatic processes [Dervisi et al., 2001]. In this study, considering the short storage condition, no significant differences in all color parameters were observed between CD samples and control fruits, except after 3 days of storage in a* values, where the control showed higher values (Table 2). In this case, the highest value of a* parameter in control samples is probably due to a decrease in respiration rate and a retarded enzymatic reaction of anthocyanins [Aday \& Caner, 2011]. After 3 days of storage, the CD samples showed significantly higher values $(\mathrm{P} \leq 0.05)$ of lightness compared with control samples. The same trend was also observed after shelf life. Therefore, the chlorine dioxide treatment had a positive effect on the lightness of strawberry color.

During the long storage condition, the $\mathrm{a}^{*}$ values decreased significantly $(\mathrm{P} \leq 0.05)$ in control and the $\mathrm{CD}$ treatment, but without significant differences between treatments $(\mathrm{P}>0.05)$. This result is in accordance with the findings of Aday \& Caner [2011] who observed significant effects of chlorine dioxide treatment on strawberry color during long storage.

During the long storage, the $\mathrm{h}^{\circ}$ and $\mathrm{L}^{*}$ values showed no significant changes in both treatments. All the samples showed, in general, no degradation of pigments caused by oxidation of $\mathrm{ClO}_{2}$, in particular regarding the degradation of red pigment. On the contrary, Gomez-Lopez et al. [2009] reported that $\mathrm{ClO}_{2}$ affects directly the degradation of red pigments.

\section{Sensory evaluation}

As indicated in Table 3, no differences were detected during short storage time, on the contrary, during the long storage time, the CD samples obtained a lower score starting from 8 days of storage. In particular, the score was influenced negatively for the color of the skin of fruits and leafs. After 8 and 12 days of storage at $2^{\circ} \mathrm{C}$, white damages were observed on the skin of treated fruits, probably caused by drops with a high concentration of chlorine dioxide that fell on the fruits. This damage deteriorated the visual quality of treated strawberries in terms of the color and overall appearance. Whitening by $\mathrm{ClO}_{2}$ treatments was reported by many authors on different fruits and vegetables [Mahovic et al., 2007; Popa et al., 2007; Sy et al., 2005b].

\section{Total soluble solids content, titratable acidity and pH}

In short storage experiment, no significant differences $(\mathrm{P}>0.05)$ were observed in terms of total soluble solids content (TSSC) and titratable acidity (TA) between control and CD treated samples (Table 4). TA values of CD treated samples were also stable with time during long storage. On the contrary, in control samples, TA values increased significantly $(\mathrm{P} \leq 0.05)$ during storage.

The results of TSSC do not show a clear trend during long storage period (Table 4), without significant influences due to 
TABLE 1. Effect of chlorine dioxide treatment of strawberries on weight loss (\%) during the short and long storage time.

\begin{tabular}{l|c|c|c|c|c}
\hline \multirow{2}{*}{ Treatments } & \multicolumn{2}{|c|}{ Short storage } & \multicolumn{3}{c}{ Long storage } \\
\cline { 2 - 6 } & 3 days & $3+2$ days & 4 days & 8 days & 12 days \\
\hline Control & $0.12 \pm 0.08^{\mathrm{a}}$ & $1.00 \pm 0.1^{\mathrm{a}}$ & $0.27 \pm 0.13^{\mathrm{aC}}$ & $1.37 \pm 0.17^{\mathrm{aB}}$ & $1.97 \pm 0.32^{\mathrm{aA}}$ \\
Chlorine dioxide & $0.13 \pm 0.07^{\mathrm{a}}$ & $1.54 \pm 2.15^{\mathrm{a}}$ & $0.16 \pm 0.06^{\mathrm{aC}}$ & $1.18 \pm 0.23^{\mathrm{bB}}$ & $1.62 \pm 0.16^{\mathrm{bA}}$ \\
\hline
\end{tabular}

Data is presented as mean $\pm \mathrm{SD}$. ${ }^{\mathrm{a}-\mathrm{b}}$ Means in the same column with different letters are significantly different $(\mathrm{p} \leq 0.05)$. ${ }^{A-B}$ In long storage, means in the same row with different letters are significantly different $(\mathrm{p} \leq 0.05)$.

TABLE 2. Effects of chlorine dioxide treatment of strawberries on color parameters $\left(\mathrm{L}^{*}, \mathrm{~h}^{\circ}, \mathrm{a}^{*}\right.$ and $\left.\mathrm{b}^{*}\right)$ during the short and long storage time.

\begin{tabular}{l|c|c|c|c|c|c|c|c}
\hline \multirow{2}{*}{$\begin{array}{l}\text { Color } \\
\text { parameters }\end{array}$} & \multirow{2}{*}{ Treatments } & \multicolumn{3}{c|}{ Short storage } & \multicolumn{4}{c}{ Long storage } \\
\cline { 3 - 9 } & & 0 day & 3 days & $3+2$ days & 0 days & 4 days & 8 days & 12 days \\
\hline \multirow{2}{*}{$L^{*}$} & Control & $32.74 \pm 3.04^{\mathrm{aA}}$ & $33.40 \pm 3.06^{\mathrm{aA}}$ & $33.83 \pm 3.58^{\mathrm{a}}$ & $32.74 \pm 3.04^{\mathrm{aA}}$ & $34.29 \pm 3.63^{\mathrm{aA}}$ & $33.75 \pm 2.94^{\mathrm{aA}}$ & $34.02 \pm 3.96^{\mathrm{aA}}$ \\
& Chlorine dioxide & $32.74 \pm 3.05^{\mathrm{aB}}$ & $34.75 \pm 3.59^{\mathrm{aA}}$ & $35.53 \pm 3.24^{\mathrm{a}}$ & $32.74 \pm 3.05^{\mathrm{aA}}$ & $33.07 \pm 2.89^{\mathrm{aA}}$ & $34.48 \pm 2.89^{\mathrm{aA}}$ & $33.68 \pm 3.86^{\mathrm{aA}}$ \\
$\mathrm{h}^{\circ}$ & Control & $33.30 \pm 4.49^{\mathrm{aA}}$ & $32.67 \pm 4.87^{\mathrm{aB}}$ & $30.18 \pm 4.20^{\mathrm{a}}$ & $33.30 \pm 4.49^{\mathrm{aA}}$ & $31.35 \pm 4.68^{\mathrm{aA}}$ & $31.10 \pm 4.03^{\mathrm{aA}}$ & $32.57 \pm 4.91^{\mathrm{aA}}$ \\
& Chlorine dioxide & $33.30 \pm 4.49^{\mathrm{aA}}$ & $33.80 \pm 5.18^{\mathrm{aA}}$ & $29.70 \pm 4.61^{\mathrm{a}}$ & $33.30 \pm 4.49^{\mathrm{aA}}$ & $30.90 \pm 3.58^{\mathrm{aA}}$ & $31.42 \pm 3.65^{\mathrm{aA}}$ & $32.26 \pm 5.75^{\mathrm{aA}}$ \\
$\mathrm{a}^{*}$ & Control & $35.79 \pm 2.39^{\mathrm{aA}}$ & $36.27 \pm 2.87^{\mathrm{aA}}$ & $33.27 \pm 5.39^{\mathrm{a}}$ & $35.79 \pm 2.39^{\mathrm{aA}}$ & $34.35 \pm 3.27^{\mathrm{aAB}}$ & $34.04 \pm 3.03^{\mathrm{aAB}}$ & $33.78 \pm 3.05^{\mathrm{aB}}$ \\
& Chlorine dioxide & $35.79 \pm 2.39^{\mathrm{aA}}$ & $34.44 \pm 3.42^{\mathrm{bA}}$ & $31.38 \pm 5.02^{\mathrm{a}}$ & $35.79 \pm 2.39^{\mathrm{aAB}}$ & $36.03 \pm 3.31^{\mathrm{aA}}$ & $33.80 \pm 3.29^{\mathrm{aBC}}$ & $33.30 \pm 3.98^{\mathrm{aC}}$ \\
$\mathrm{b}^{*}$ & Control & $23.67 \pm 4.02^{\mathrm{aA}}$ & $23.46 \pm 4.52^{\mathrm{aA}}$ & $19.8 \pm 5.80^{\mathrm{a}}$ & $23.67 \pm 4.02^{\mathrm{aA}}$ & $21.1 \pm 4.06^{\mathrm{aB}}$ & $20.66 \pm 3.50^{\mathrm{aB}}$ & $21.64 \pm 3.63^{\mathrm{aAB}}$ \\
& Chlorine dioxide & $23.67 \pm 4.02^{\mathrm{aA}}$ & $23.17 \pm 4.25^{\mathrm{aA}}$ & $18.39 \pm 5.54^{\mathrm{a}}$ & $23.67 \pm 4.02^{\mathrm{aA}}$ & $21.76 \pm 4.07^{\mathrm{aA}}$ & $20.84 \pm 4.18^{\mathrm{aA}}$ & $21.32 \pm 5.52^{\mathrm{aA}}$ \\
\hline
\end{tabular}

Data is presented as mean \pm SD of 15 replicates. ${ }^{\text {a-b }}$ Means in the same column with different letters are significantly different ( $(p \leq 0.05)$. ${ }^{A-B}$ Means in the same row with different letters are significantly different $(\mathrm{p} \leq 0.05)$, statistical analysis was carried out separately for short and long storage.

TABLE 3. Sensory index of strawberry samples during the short and long storage time.

\begin{tabular}{l|c|c|c|c|c|c|c}
\hline \multirow{2}{*}{ Treatments } & \multicolumn{3}{|c|}{ Short storage } & \multicolumn{4}{c}{ Long storage } \\
\cline { 2 - 8 } & 0 day & 3 days & $3+2$ days & 0 days & 4 days & 8 days & 12 days \\
\hline Control & $39.51 \pm 0.21^{\mathrm{aA}}$ & $38.0 \pm 0.14^{\mathrm{aA}}$ & $36.0 \pm 0.24^{\mathrm{a}}$ & $39.0 \pm 0.25^{\mathrm{aA}}$ & $37.0 \pm 0.17^{\mathrm{aA}}$ & $32.0 \pm 0.18^{\mathrm{aB}}$ & $29.5 \pm 0.23^{\mathrm{aB}}$ \\
Chlorine dioxide & $39.0 \pm 0.32^{\mathrm{aA}}$ & $38.0 \pm 0.16^{\mathrm{aA}}$ & $36.0 \pm 0.31^{\mathrm{a}}$ & $39.0 \pm 0.14^{\mathrm{aA}}$ & $37.0 \pm 0.21^{\mathrm{aA}}$ & $28.0 \pm 0.19^{\mathrm{bB}}$ & $26.5 \pm 0.17^{\mathrm{bB}}$ \\
\hline
\end{tabular}

Data is presented as mean \pm SD of 6 replicates. ${ }^{a-b}$ Means in the same column with different letters are significantly different ( $(p \leq 0.05)$. ${ }^{A-B}$ Means in the same row with different letters are significantly different $(\mathrm{p} \leq 0.05)$, statistical analysis was carried out separately for short and long storage.

CD treatment. This is in contrast with the results of Aday \& Caner [2011], who report a significant influence of the chlorine dioxide treatment on qualitative parameters of strawberries.

After 12 days of storage, CD samples showed significantly higher values of $\mathrm{pH}(\mathrm{P} \leq 0.05)$ compared with the control and the $\mathrm{pH}$ values at time 0 (Table 4). Aday \&d Caner [2011] showed that an increase of $\mathrm{pH}$ can be due to chlorine dioxide treatment.

\section{Total anthocyanin content}

The content of anthocyanins was stable during the short storage time and decreased during long storage (Table 5) without significant differences between treatments. These results are in agreement with Mullen et al. [2002] who observed a similar result during cold storage.

Orak [2007] showed that the content of anthocyanins in red grapes of different cultivars was strictly correlated with $\mathrm{pH}$ of fruits. In the presented study, both total anthocyanins content and $\mathrm{pH}$ values did not change due to chloride dioxide treatment, except after shelf-life.

\section{Total phenolics content}

During short storage period in cold $\left(4^{\circ} \mathrm{C}\right)$ no significant changes $(\mathrm{P}>0.05)$ in total phenolics content of strawberries were found between $\mathrm{CD}$ treated and control samples. After 2 days at $20^{\circ} \mathrm{C}$, the control showed a higher value than the $\mathrm{CD}$ treated samples (Table 5). No significant differences in total phenolics content $(\mathrm{P}>0.05)$ were also observed during long storage period at $2{ }^{\circ} \mathrm{C}$ for both comparisons: control-treaded samples and with time of storage. The study of Napolitano et al. [2005] has shown that chlorine dioxide can promote oxidative reaction with $\mathrm{pH}$ values higher than 4 and thereby cause the oxidation of phenols present in the reaction mixture. In the present work, it is possible that during storage the chlorine dioxide was not sufficient to enhance the oxidative reaction in fruits. The reason can be the low $\mathrm{pH}$ value 


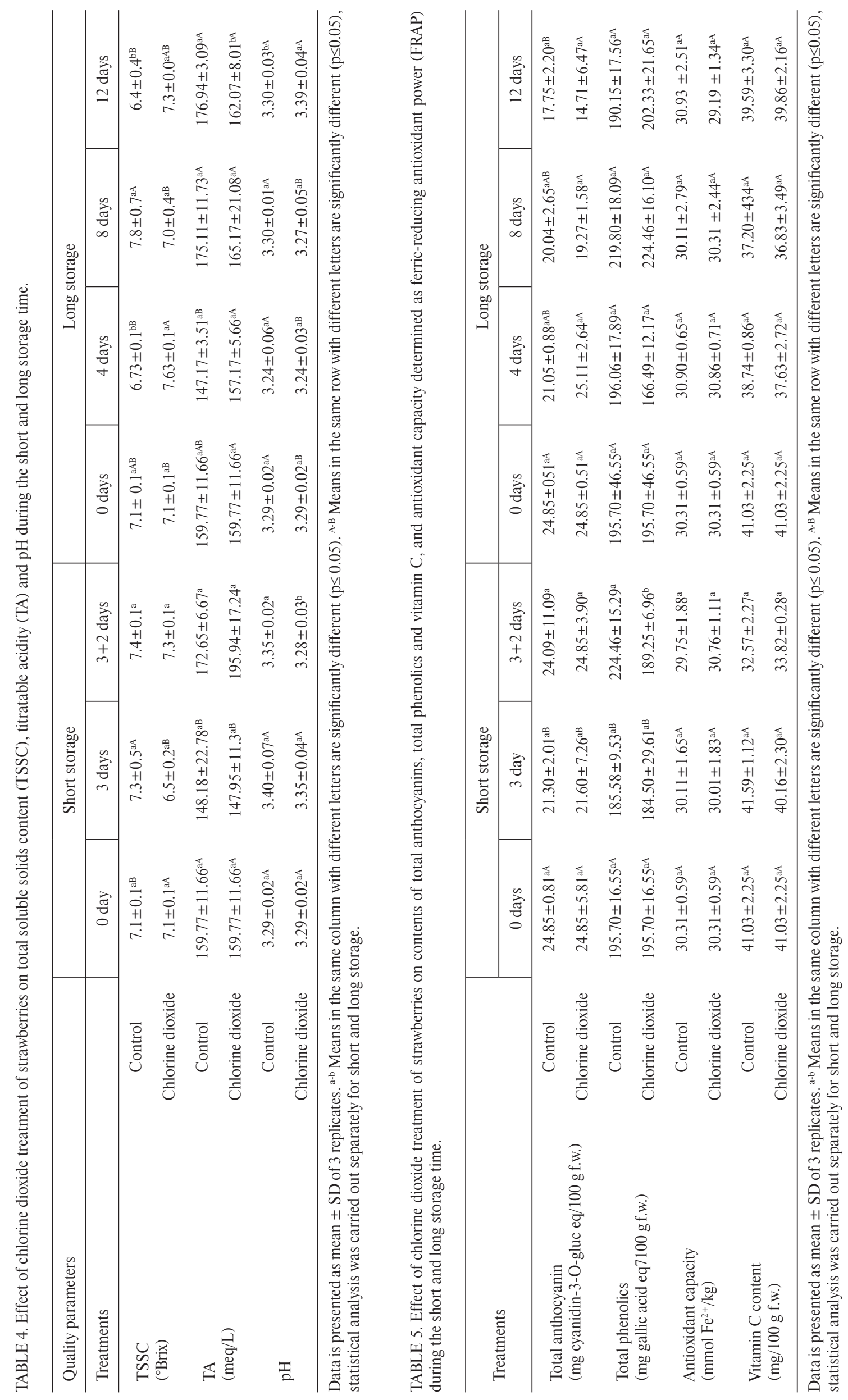


TABLE 6. Effect of chlorine dioxide treatment of strawberries on molds and yeast count during the long storage time.

\begin{tabular}{lccc|c|c}
\hline Treatments & & 0 days & 4 days & 8 days & 12 days \\
\hline Mold & Control & $3.7 \pm 0.21^{\mathrm{aB}}$ & $3.1 \pm 0.34^{\mathrm{aB}}$ & $4.4 \pm 0.51^{\mathrm{aA}}$ & $4.4 \pm 0.42^{\mathrm{aA}}$ \\
$($ Log CFU/g) & Chlorine dioxide & $3.7 \pm 0.21^{\mathrm{aA}}$ & $2.3 \pm 0.25^{\mathrm{bB}}$ & $1.9 \pm 0.12^{\mathrm{bB}}$ & $3.8 \pm 0.33^{\mathrm{bA}}$ \\
Yeast & Control & $3.1 \pm 0.22^{\mathrm{aB}}$ & $2.6 \pm 0.15^{\mathrm{aB}}$ & $4.0 \pm 0.12^{\mathrm{aA}}$ & $4.4 \pm 0.34^{\mathrm{aA}}$ \\
$($ Log CFU/g) & Chlorine dioxide & $3.1 \pm 0.22^{\mathrm{aB}}$ & $2.8 \pm 0.16^{\mathrm{aB}}$ & $2.3 \pm 0.25^{\mathrm{bB}}$ & $4.8 \pm 0.31^{\mathrm{aA}}$ \\
\hline
\end{tabular}

Data is presented as mean $\pm \mathrm{SD}$ of 3 replicates. ${ }^{a-b}$ Means in the same column with different letters are significantly different ( $\mathrm{p} \leq 0.05$ ). ${ }^{\mathrm{A}-\mathrm{B}}$ Means in the same row with different letters are significantly different $(\mathrm{p} \leq 0.05)$, statistical analysis was carried out separately for short and long storage.

of the samples (Table 4). Hence, the use of chlorine dioxide did not affect the total phenolics content.

\section{Antioxidant capacity}

During both evaluated storage periods no significant differences $(\mathrm{P}>0.05)$ were observed in the antioxidant capacity of strawberries between the $\mathrm{CD}$ treated and control samples (Table 5). The level of total antioxidant capacity was stable in accordance with Prior et al. [1998] and in contrast with the studies of Mullen et al. [2002] and Kalt et al. [1999], who found an increase of total antioxidant capacity during storage. The treatment with chlorine dioxide does not seem to have a perceptible impact on the total antioxidant capacity [Napolitano et al., 2005].

\section{Vitamin $C$ analysis}

Vitamin $\mathrm{C}$ content of strawberries did no differ significantly $(\mathrm{P}>0.05)$ between the treated and control samples in the short storage experiment (Table 5). A slow decrease of vitamin $\mathrm{C}$ content was observed after 3 days at $4^{\circ} \mathrm{C}$ and after 2 days at $20^{\circ} \mathrm{C}$. Concerning the long storage time, the vitamin $\mathrm{C}$ content decreased slowly in both samples with no significant differences between samples and during storage, which is in agreement with the studies of Kalt et al. [1999] and Haffner et al. [2002].

\section{Yeast and mold evaluation}

Visible molds were not observed during the experiment. At 0 days, the counts of molds and yeast were 3.7 and $3.1 \log$ $\mathrm{CFU} / \mathrm{g}$, respectively (Table 6). In this study, the effect of $\mathrm{ClO}_{2}$ gas treatments was evident on the growth of molds after 4 and 8 days of storage. After 4 days of cold storage, in $\mathrm{CD}$ samples the count of molds decreased by $1.5 \mathrm{log}$ CFU/g and after 8 days by $1.8 \log \mathrm{CFU} / \mathrm{g}$, compared to day 0 . The $\mathrm{CD}$ treatment reduced also the yeast count from $3.1 \mathrm{log}$ $\mathrm{CFU} / \mathrm{g}$ to $2.8 \log \mathrm{CFU} / \mathrm{g}$ after 4 days and to $2.3 \log \mathrm{CFU} / \mathrm{g}$ after 8 days. After 12 days, the level of yeast and molds increased probably because the effect of $\mathrm{CD}$ pad was finished.

Concerning the control samples, the count of molds decreased after 4 days and increased after 8 and 12 days of cold storage. The same result was observed for the yeast count.

These results are consistent with those reported by Sun et al. [2014] showing that the treatment with $\mathrm{ClO}_{2}$ reduced significantly the population of total bacteria count and total yeast count during blueberries storage at $10^{\circ} \mathrm{C}$.

\section{CONCLUSION}

Chlorine dioxide is known to be a strong oxidizing agent used to decontaminate minimally processed fruits and vegetables against a great number of microorganisms. The present study showed the action of $\mathrm{ClO}_{2}$ against the natural decay and growth of microorganisms and its effect on the quality under two different storage conditions. In particular, the effect of treatment was positive on the reduction of the weight loss and on the microbial proliferation and was in general not detectable regarding the quality parameters considered. After 12 days of storage, we observed that the effectiveness of chlorine dioxide treatment was limited, probably because the gas generating pads were exhausted. In conclusion, the applied treatment of gaseous chlorine may be suitable to preserve the post-harvest quality during short storage (3 days at $4^{\circ} \mathrm{C}+2$ days at $20^{\circ} \mathrm{C}$ ) and until 8 days in a long storage at $2^{\circ} \mathrm{C}$. Moreover, it can be an important alternative sanitizer thanks to the positive action against the yeast and molds without the necessity of product washing.

\section{RESEARCH FUNDING}

This study was supported by the University of Turin - Local Research.

\section{CONFLICT OF INTEREST}

The authors declare no potential conflicts of interest.

\section{REFERENCES}

1. Aday M.S., Büyükcan M.B., Caner C., Maintaining the quality of strawberries by combined effect of aqueous chlorine dioxide with modified atmosphere packaging. J. Food Proc. Preserv., 2013, 37, 568-581.

2. Aday M.S., Caner C., The applications of 'active packaging and chlorine dioxide' for extended shelf life of fresh strawberries. Packag. Technol. Sci., 2011, 24, 123-136.

3. Appendini P., Hotchkiss J.H., Review of antimicrobial food packaging. Innov. Food Sci. Emerg. Technol., 2002, 3, 113-126.

4. Bonarska-Kujawa D., Sarapuk J., Bielecki K., Oszmiański J., Kleszczyńska H., Antioxidant activity of extracts from apple, chokeberry and strawberry. Pol. J. Food Nutr. Sci., 2012, 62, 229-234.

5. Cao S., Hu Z., Pang B., Optimization of postharvest ultrasonic treatment of strawberry fruit. Post. Biol. Technol., 2010, 55, 3, 150-153. 
6. Cheng G.W., Breen P.J., Activity of phenylalanine ammonialyase (PAL) and concentrations of anthocyanins and phenolics in developing strawberry fruit. J. Am. Soc. Hort. Sci., 1991, 116, 865-869.

7. Chiabrando V., Giacalone G., Anthocyanins, phenolics and antioxidant capacity after fresh storage of blueberry treated with edible coatings. Int. J. Food Sci. Nutr., 2015, 66, 248-253.

8. Colgecen I., Aday M.S., The efficacy of the combined use of chlorine dioxide and passive modified atmosphere packaging on sweet cherry quality. Post. Biol. Technol., 2015, 109, 10-19.

9. Dervisi P., Lamb J., Zabetakis I., High pressure processing in jam manufacture: effects on textural and colour properties. Food Chem., 2001, 73, 1, 85-91.

10. Gomez-Lopez V.M., Rajkovic A., Ragaert P., Smigic N., Devlieghere F., Chlorine dioxide for minimally processed produce preservation: a review. Trends Food Sci. Technol., 2009, 20, 17-26.

11. Gonzalez-Molina E., Moreno D.A., García-Viguera C., Genotype and harvest time influence the phytochemical quality of Fino lemon juice (Citrus limon (L.) Burm. F.) for industrial use. J. Agric. Food Chem., 2008, 56, 1669-1675.

12. Guo Q., Lv X., Xu F., Zhang Y., Wang J., Lin H., Wu B., Chlorine dioxide treatment decreases respiration and ethylene synthesis in fresh-cut 'Hami'melon fruit. Int. J. Food Sci. Technol., 2013, 48, 1775-1782.

13. Haffner K., Rosenfeld H.J., Skrede G., Wang L., Quality of red raspberry Rubus idaeus L. cultivars after storage in controlled and normal atmospheres. Postharv. Biol. Technol., 2002, 24, 279-289.

14. Han Y., Linton R.H., Nielsen S.S., Nelson P.E., Reduction of Listeria monocytogenes on green peppers (Capsicum annuum L.) by gaseous and aqueous chlorine dioxide and water washing and its growth at $7^{\circ} \mathrm{C}$. J. Food Prot., 2001, 64, 1730-1738.

15. Hernandez-Munoz P., Almenar E., Valle V.D., Velez D., Gavara R., Effect of chitosan coating combined with postharvest calcium treatment on strawberry (Fragaria ananassa) quality during refrigerated storage. Food Chem., 2008, 110, 428-435.

16. Kalt W., Forney C.F., Martin A., Prior R.L., Antioxidant capacity, vitamin $\mathrm{C}$, phenolics and anthocyanins after fresh storage of small fruits. J. Agric. Food Chem., 1999, 47, 4638-4644.

17. Lopez-Gomez P.S., Palop F.A., Periago P.M, Martinez-Lopez A., Marin-Iniesta F., Barbosa-Canovas G.V., Food safety engineering: an emergent perspective. Food Eng. Rev., 2009, 1, 84-104.

18. Maas J.L., Compendium of Strawberry Diseases, APS Press, 1998, pp. 44-46.

19. Mahovic M.J., Tenney J.D., Bartz J.A., Applications of chlorine dioxide gas for control of bacterial soft rot in tomatoes. Plant Dis., 2007, 91, 1316-1320.

20. Mullen W., McGinn J., Lean M.E., MacLean M.R., Gardner P., Duthie G.G., Crozier A., Ellagitannins, flavonoids and other phenolics in red raspberries and their contribution to antioxidant capacity and vasorelaxation properties. J. Agric. Food Chem., 2002, 50, 5191-5196.

21. Napolitano M.J., Green B.J., Nicoson J.S., Margerum D.W., Chlorine dioxide oxidation of tyrosine, N-acetyltyrosine and dopa. Chem. Res. Toxicol., 2005, 18, 501-508.

22. Orak H.H., Total antioxidant activities, phenolics, anthocyanins, polyphenoloxidase activities of selected red grape cultivars and their correlations. Sci. Hortic., 2007, 111, 235-241.
23. Peano C., Girgenti V., Giuggioli N., Change in quality and volatile constituents of strawberries (cv. Evie2) under MAP storage. J. Food Agric. Environ., 2014, 12, 93-100.

24. Pellegrini N., Serafini M., Colombi B., Del Rio D., Salvatore S., Bianchi M., Brighenti F., Total antioxidant capacity of plant foods, beverages and oils consumed in Italy assessed by three different in vitro assays. J. Nutr., 2003, 133, 2812-2819.

25. Popa I., Hanson E.J.D., Todd E.C.D., Schilder A.C., Ryser E.T., Efficacy of chlorine dioxide gas sachets for enhancing the microbiological quality and safety of blueberries. J Food Prot., 2007, 70, 2084-2088.

26. Prior R.L., Cao G., Martin A., Sofic E., McEwen J., O’Brien C., Mainlan C.M., Antioxidant capacity as influenced by total phenolic and anthocyanin content, maturity and variety of Vaccinium species. J. Agric. Food Chem., 1998, 46, 2686-2693.

27. Saengnil K., Chumyam A., Faiyue B., Uthaibutra J., Use of chlorine dioxide fumigation to alleviate enzymatic browning of harvested 'Daw' longan pericarp during storage under ambient conditions. Post. Biol. Technol., 2014, 91, 49-56.

28. Sanchez-Moreno C., Plaza L., De Ancos B., Cano M.P., Quantitative bioactive compounds assessment and their relative contribution to the antioxidant capacity of commercial orange juices. J. Sci. Food Agric., 2003, 83, 430-439.

29. Shin Y.J., Song H.Y., Song B.K., Effect of a combined treatment of rice bran protein film packaging with aqueous chlorine dioxide washing and ultraviolet-C irradiation on the postharvest quality of 'Goha' strawberries. J. Food Engin., 2012, 113, 374-379.

30. Sun X., Bai J., Ference C., Wang Z., Zhang Y., Narciso J., Zhou K., Antimicrobial activity of controlled-release chlorine dioxide gas on fresh blueberries. J. Food Prot., 2014, 77, 1127-1132.

31. Sy K.V., McWatters, K.H., Beuchat L.R., Efficacy of gaseous chlorine dioxide as a sanitizer for killing Salmonella, yeasts, and molds on blueberries, strawberries, and raspberries. J. Food Prot., 2005a, 68, 1165-1175.

32. Sy K.V., Murray M.B., Harrison M.D., Beuchat L.R., Evaluation of gaseous chlorine dioxide as a sanitizer for killing Salmonella, Escherichia coli O157:H7, Listeria monocytogenes, and yeasts and molds on fresh and fresh-cut produce. J. Food Prot., 2005b, 68, 1176-1187.

33. Vanderzant C., Splittstoesser D.F., Compendium of Methods for the Microbiological Examination of Food. Splittstoesser Eds., 1992, Washington, DC.

34. Vargas M., Albors A., Chiralt A., González-Martínez C., Quality of cold-stored strawberries as affected by chitosan-oleic acid edible coatings Post. Biol. Technol., 2006, 41, 164-171.

35. Wang Y., Wu J., Ma D., Ding J., Preparation of a cross-linked gelatin/bacteriorhodopsin film and its photochromic properties. Sci. China Chem., 2011, 54, 405-409.

36. Waterhouse A.L., Polyphenolics: Determination of total phenolics. 2002, in: Current Protocols in Food Analytical Chemistry (ed. R.E. Wrolstad). John Wiley \& Sons, New York, U.S.A., pp. I1.1.1-I1.1.8.

37. Wu B., Guo Q., Wang G., Peng W., Wang J., Che F., Effects of different postharvest treatments on the physiology and quality of 'Xiaobai' apricots at room temperature. J. Food Sci. Technol., 2015, 52, 2247-2255.

38. Zhang L., Yan Z., Hanson E.J., Ryser E.T., Efficacy of chlorine dioxide gas and freezing rate on the microbiological quality of frozen blueberries. Food Contr., 2015, 47, 114-119. 
39. Zhong M., Wu B., Wang J., Wu J., Wei L., Effect of chlorine dioxide on ripening of 'Xiaobai' apricots. Eur. Food Res. Technol., 2006, 223, 791-795.
Submitted: 7 February 2017. Revised: 26 May and 12 July 2017. Accepted: 24 July 2017. Published on-line: 6 November 2017. 